\title{
BIOSORPSI LOGAM Zn PADA LIMBAH SINTETIK MENGGUNAKAN BIOMASSA CAMPURAN Pseudomonas aeruginosa DAN Pseudomonas sp
}

\section{Biosorption of Zinc on Synthetic Waste Using Pseudomonas aeruginosa and Pseudomonas sp Biomass Consortia}

Hidayati*, Uray Lusiana dan Yoyon Suyono

Baristand Industri Pontianak, JI. Budi Utomo No. 41, Pontianak

*e-mail: hidayati@kemenperin.go.id

Diterima: 12 Agustus 2013, Revisi akhir: 7 November 2013 dan disetujui untuk diterbitkan: 18 November 2013

\section{ABSTRAK}

Salah satu logam berat yang berbahaya dari hasil kegiatan industri adalah logam Zn (seng). Biosorpsi logam Zn pada limbah sintetik dilakukan dengan menggunakan biomassa campuran Pseudomonas aeruginosa dan Pseudomonas sp. Penelitian ini bertujuan untuk mengetahui kapasitas biomassa dalam mengadsorpsi logam Zn pada limbah sintetik. Biosorpsi logam Zn dilakukan pada kondisi $\mathrm{pH} 4$, temperatur ruang dan pengadukan $800 \mathrm{rpm}$. Variasi waktu kontak dilakukan pada 30, 60 dan 120 menit dan menggunakan jumlah biomassa 0,01 g, 0,02 g, 0,03g, $0,04 \mathrm{~g}$ dan $0,05 \mathrm{~g}$. Kapasitas biosorpsi logam Zn tertinggi diperoleh sebesar $25,43 \%$ pada waktu 120 menit dengan jumlah biomassa 0,01 g. Kondisi optimum biosorpsi logam Zn berdasarkan korelasi antara data eksperimen dan model matematika diperoleh pada penambahan jumlah biomassa sebesar 0,04 g baik untuk kapasitas biosorpsi logam $\mathrm{Zn}$ maupun efisiensi removal logam Zn dengan nilai koefisien korelasi $\left(R^{2}\right)$ masing-masing adalah 1 dan 0,965.

\section{Kata Kunci : Biosorpsi, koefisien korelasi, Zn, Pseudomonas}

\begin{abstract}
Zinc is one of the heavy metals that could be harmful for environment. This metal usually arises from industrial activities. Biosorption of zinc in synthetic waste was conducted using biomass mixture of Pseudomonas aeruginosa and Pseudomonas sp. This research aims to determine the zinc adsorption capacity of the biomass in synthetic waste water. Zinc biosorption was performed at $\mathrm{pH} \mathrm{4,} \mathrm{room} \mathrm{temperature} \mathrm{and} \mathrm{stirring} 800 \mathrm{rpm}$. Variation of contact time used was 30, 60 and $120 \mathrm{~min}$; and the amount of biomass used was $0.01 \mathrm{~g}, 0.02 \mathrm{~g}, 0.03 \mathrm{~g}, 0.04 \mathrm{~g}$ and 0.05 g. The highest zinc biosorption capacity was obtained $25.43 \%$ at the time of 120 minutes and the amount of biomass used $0.01 \mathrm{~g}$. The optimum condition for biomass biosorption and removal capacity based on the correlation between experimental data and mathematical models was obtained with the addition of $0.04 \mathrm{~g}$ of biomass with correlation coefficient $\left(R^{2}\right) 1$ and 0,965 respectively.
\end{abstract}

Keywords: Biosorption, correlation coefficient, Zn, Pseudomonas

\section{PENDAHULUAN}

Saat ini, pengolahan limbah secara biologis untuk mengurangi ion logam berat dari air tercemar menjadi teknologi alternatif yang berpotensi untuk dikembangkan. Ada beberapa cara pengolahan limbah, salah satunya adalah biosorpsi yang memanfaatkan kemampuan pertukaran ion, pembentukan kompleks dan penyerapan mikroorganisme untuk menyerap logam berat (Kresnawaty dkk., 2007). Secara umum, keuntungan pemanfatan mikroorganisme sebagai biosorben adalah (1) biaya operasional rendah, (2) efisiensi dan kapasitas pengikatan logam yang tinggi, (3) meminimumkan terbentuknya sludge, (4) kemungkinan untuk recovery logam, (5) biosorben dapat diregenerasi, (6) bahan 
bakunya mudah didapat dan tersedia dalam jumlah banyak, dan (7) tidak memerlukan tambahan nutrisi jika menggunakan mikroba yang sudah mati (Gazsó, 2001; Ahalya et.al, 2004).

Mikroba telah lama diketahui dapat menyerap logam-logam berat dari lingkungan eksternalnya secara efisien (Horsfall et.al., 2006; Chergui et.al., 2007). Bakteri genus Pseudomonas banyak digunakan sebagai biomaterial biosorben karena memiliki kemampuan menyerap barbagai logam seperti chromium (VI), copper $(\mathrm{Cu})$, cadmium $(\mathrm{Cd})$, Plumbum $(\mathrm{Pb})$, zinc $(\mathrm{Zn})$ dengan $\mathrm{pH}$ proses mendekati netral (4-7) dan waktu kontak mulai 1 jam hingga 24 jam (Vijayaraghavan et.al., 2008).

Penelitian biomaterial bakteri Pseudomonas dalam biosorpsi logam sudah banyak dipublikasikan (Vijayaraghavan et.al.; Wang et.al., 2009), seperti berikut: (1) Biosorpsi logam Chromium (VI) $\left(\mathrm{Cr}^{+6}\right)$ oleh bakteri Pseudomonas sp (Ziagova et.al., 2007). (2) Biosorpsi logam Copper (Cu) oleh bakteri Pseudomonas aeruginosa (Chang et.al., 1997), Pseudomonas cepacia (Savvaidis, et.al., 2003), Pseudomonas putida (Pardo et.al., 2003; Uslu dan Tanyol et.al., 2006), Pseudomonas putida CZI (Chen et.al., 2005), dan Pseudomonas stutzeri IAM 12097 (Nakajima et.al., 2001). (3) Biosorpsi logam Cadmium (Cd) oleh bakteri Pseudomonas aeruginosa PU21 (Lu et.al., 1997), Pseudomonas putida (Pardo et.al., 2003) dan Pseudomonas sp (Ziagova et.al., 2007). (4) Biosorpsi logam Plumbum $(\mathrm{Pb})$ oleh bakteri Pseudomonas aeruginosa PU21 (Chang et.al., 1997; Lin dan Lai, 2006) dan Pseudomonas putida (Pardo et.al., 2003; Uslu dan Tanyol et.al., 2006). (5) Biosorpsi logam Zinc ( $\mathrm{Zn}$ ) oleh bakteri Pseudomonas putida (Pardo et.al., 2003) dan Pseudomonas putida CZI (Chen et.al., 2005).

Pemanfaatan biomaterial didasarkan pada sifat biologi berupa kapasitas pengikatan logam (metal-binding capacities) dengan metode biosorpsi. Biosorpsi dapat didefinisikan sebagai interaksi tidak langsung secara fisika-kimia antara logam/radionukleotida dan sel mikroba (Shumate dan Stranberg, 1985 dalam Alluri, et.al, 2007). Mekanisme biosorpsi berdasarkan metabolisme sel dapat dibagi dua yaitu metabolisme dependent dan nonmetabolisme dependent. Tempat dimana logam dapat diserap dari larutan salah satunya adalah melalui cell surface sorption (permukaan sel).

Mekanisme non-metabolisme dependent dengan cell surface sorption dapat menggunakan bakteri pasif (non living cells) melalui interaksi fisika-kimia antara logam dengan gugus fungsional yang terdapat pada dinding sel. Dinding sel tersusun atas polisakarida, liposakarida, glikoprotein yang mampu mengikat logam. Metode ini relatif cepat, reversibel (Kuyucak dan Volesky, 1988 dalam Ahalya, et al., 2004) dan tanpa penambahan nutrien (Hussein, et al., 2004). Tahapan biosorpsi meliputi pemilihan biomaterial, pretreatment biomaterial, imobilisasi biosorben (pembuatan biosorben) dan biosorpsi (Alluri, et.al., 2007).

Biomasa berupa bakteri pasif/mati diimobilisasi menggunakan Ca-alginat didasarkan pada penggunaan sel bebas yang memiliki keterbatasan, diantaranya ukuran kecil, densitas rendah, kekuatan mekanis rendah, kurang rigit yang dapat memberikan masalah pemisahan padat-cair (solid-liquid), swelling (menambah besar) biomassa, tidak dapat digunakan ulang dan terjadi pengembangan tetesan tekanan tinggi dalam kolom. Tekanan tinggi dapat menyebabkan disintegrasi biomassa bebas dan masalah tersebut dapat diatasi melalui penggunaan sistem imobilisasi sel (Gupta, et al., 2000).

Teknik imobilisasi menggunakan media Ca-alginat dipilih karena berasal dari alga coklat yang merupakan bahan dasar alginat yang banyak dibudidayakan di Indonesia serta diharapkan mempunyai nilai ekonomis (Widjaja, 2008). Disamping itu, Ca-alginat telah banyak digunakan dalam beberapa penelitian (Alluri et.al., 2007), seperti (1) adsorpsi logam Cd oleh biomassa Luffa cylindrical (lqbal et.al.,1997), (2) adsorpsi logam $\mathrm{Cu}$ dan $\mathrm{Ni}$ oleh biomassa Chryseomonas luteola (Guven et.al., 2005), (3) adsorpsi logam $\mathrm{Cu}, \mathrm{Cd}$ dan $\mathrm{Pb}$ oleh biomassa Laminaria digitata (Sergios et.al., 2006), (4) adsorpsi logam Pb oleh biomassa Bacillus cereus (Paul et.al., 2006), (5) adsorpsi logam $\mathrm{Cr}(\mathrm{VI})$ oleh biomassa Cyanobacterium (Bala, et.al., 2007) dan (6) 
adsorpsi logam $\mathrm{Cr}, \mathrm{Mn}, \mathrm{Fe}, \mathrm{Ni}, \mathrm{Cu}$ dan $\mathrm{Pb}$ oleh Polyporus squamosus Wuyep, et.al., 2007). Imobilisasi sel/biomassa dalam struktur solid dapat menghasilkan material biosorben dengan ukuran yang tepat, kekuatan mekanis, rigit, dan porositas yang diperlukan untuk penggunaannya dalam proses pengolahan (treatment). Faktorfaktor yang mempengaruhi biosorpsi antara lain adalah $\mathrm{pH}$ larutan, temperatur, jumlah biosorben, ukuran biosorben, konsentrasi awal, kecepatan pengadukan, waktu dan kekuatan ion (Vijayaraghavan et.al., 2008).

Dalam upaya pengembangan biodiversitas lokal khususnya bakteri resisten logam yang berasal dari lokasi industri pelapisan seng di Kalimantan Barat sebagai biomaterial biosorben maka dilakukan pengolahan limbah cair yang mengandung logam $\mathrm{Zn}$ dengan metode biosorpsi menggunakan biomassa campuran bakteri Pseudomonas aeruginosa dan Pseudomonas sp. Disamping itu juga untuk mendapatkan kondisi optimum biosorpsi dengan mekanisme nonmetabolisme dependent dengan proses cell surface sorption/precipitation menggunakan mikroorganisme pasif/mati (non living cells).

\section{METODOLOGI PENELITIAN}

Bahan yang digunakan adalah biomaterial berupa campuran bakteri $P$ seudomonas aeruginosa dan Pseudomonas $s p$ hasil isolasi dan identifikasi pada tanah/lokasi dekat instalasi pengolahan air limbah (IPAL) industri pelapisan seng Kalbar (dekat titik outlet), NaAlginat, $\mathrm{NaCl}, \mathrm{CaCl}_{2}$ dan bahan-bahan untuk pengujian logam Zn. Peralatan yang digunakan meliputi timbangan analitik, timbangan top loading, cawan petri, jarum ose, pipet ukur, labu ukur, gelas kimia, erlenmeyer, oven, hot plate stirer, pinset, $\mathrm{pH}$ meter, termometer, atomic absorption spectroscopy (AAS) dan centrifuge. Rancangan penelitian menggunakan faktor berupa jumlah biosorben dengan variasi berat $0,01 \mathrm{~g}, 0,02 \mathrm{~g}, 0,03 \mathrm{~g}, 0,04 \mathrm{~g}$ dan 0,05 $\mathrm{g}$ dan waktu kontak proses biosorpsi selama 30, 60 dan 120 menit pada kondisi $\mathrm{pH} 4$.

\section{Pembuatan Sel Kering (Dry Cell)}

Biomassa berupa campuran bakteri
Pseudomonas aeruginosa dan Pseudomonas $s p$ yang resisten logam berat ditumbuhkan dalam Casamino Acid Media (CAA) pada suhu $25-35^{\circ} \mathrm{C}$ selama $24-28$ jam pada rotary shaker $200 \mathrm{rpm}$. Selanjutnya biomassa dipisahkan dari medium menggunakan centrifuge $8000 \mathrm{rpm}$ selama 15 menit. Suspended yang dihasilkan selanjutnya dikeringkan pada suhu $70^{\circ} \mathrm{C}$ selama 120 menit sehingga diperoleh sel kering (dry cell).

\section{Pembuatan Biosorben}

Sel kering dihaluskan dan ditimbang dengan berat masing-masing $0,01 \mathrm{~g}, 0,02 \mathrm{~g}$, $0,03 \mathrm{~g}, 0,04 \mathrm{~g}$ dan $0,05 \mathrm{~g}$. Selanjutnya masing-masing dicampurkan ke dalam $10 \mathrm{ml}$ larutan Na-Alginat $2 \%$ dan diaduk menggunakan vortex. Campuran tersebut diteteskan ke dalam larutan $\mathrm{CaCl}_{2}$ hingga terbentuk butiran (beads) dan didiamkan selama 1 (satu) malam. Biosorben dalam bentuk butiran disaring menggunakan kertas saring dan dibilas dengan larutan $\mathrm{NaCl} 1 \%$ sebanyak 3 kali dan terakhir dengan akuades.

\section{Biosorpsi Logam Zn}

Biosorben dengan variasi berat $0,01 \mathrm{~g}$, $0,02 \mathrm{~g}, 0,03 \mathrm{~g}, 0,04 \mathrm{~g}$, dan $0,05 \mathrm{~g}$ dicampurkan dalam larutan $100 \mathrm{ml}$ limbah sintetik yang mengandung logam seng dengan konsentrasi $\pm 7-10 \mathrm{mg} / \mathrm{L}$ dan pengadukan 700 rpm. $\mathrm{pH}$ diatur 4 pada suhu kamar. Waktu kontak masing-masing proses adalah 30, 60 dan 120 menit. Setelah kontak, larutan yang mengandung biosorben disaring. Bagian filtratnya dilakukan pengujian menggunakan AAS untuk mengetahui logam berat yang terserap (Sesuai SNI 06-6989.7-2004).

\section{Perhitungan Logam Zn yang Terserap}

Konsentrasi (C) logam Zn yang terserap untuk tiap waktu dihitung dengan Persamaan (1):

$$
C=\left(C_{\text {awal }}-C_{\text {akhir }}\right)
$$

Biosorpsi logam $\mathrm{Zn}$ oleh biomassa dihitung dari perbedaan kadar $\mathrm{Zn}$ awal yang diinteraksikan pada biomassa dan kadar $\mathrm{Zn}$ pada filtrat setelah diinteraksikan pada 
biomassa dengan menggunakan Persamaan (2) (Vijayaraghavan et.al., 2008).

$$
\mathrm{Q}=\frac{\left(C_{o}-C_{f}\right) V}{W}
$$

dengan $Q=$ jumlah ion logam yang terserap ( $\mathrm{mg}$ adsorbat $/ \mathrm{g}$ adsorban), $\mathrm{C}_{0}=$ konsentrasi awal ion logam dalam larutan $(\mathrm{mg} / \mathrm{L}), \mathrm{C}_{\mathrm{f}}=$ konsentrasi akhir ion logam setelah setimbang $(\mathrm{mg} / \mathrm{L}), \mathrm{V}=$ volume larutan ion logam $(L)$ dan $W=$ jumlah biosorben yang ditambahkan $(\mathrm{g})$.

\section{HASIL DAN PEMBAHASAN}

\section{Konsentrasi Logam Zn yang Terserap}

Gambar 1 menunjukkan konsentrasi logam $\mathrm{Zn}$ yang terserap seiring dengan bertambahnya waktu dan penambahan biomassa. Semakin banyak jumlah biomassa yang ditambahkan seiring dengan bertambahnya waktu maka semakin besar jumlah logam $\mathrm{Zn}$ yang terserap. konsentrasi logam Zn yang paling banyak terserap diperoleh pada waktu 120 menit dengan jumlah biomassa $0,05 \mathrm{~g}$ adalah $4,8933 \mathrm{mg} / \mathrm{L}$ padakondisi $\mathrm{pH} 4$.

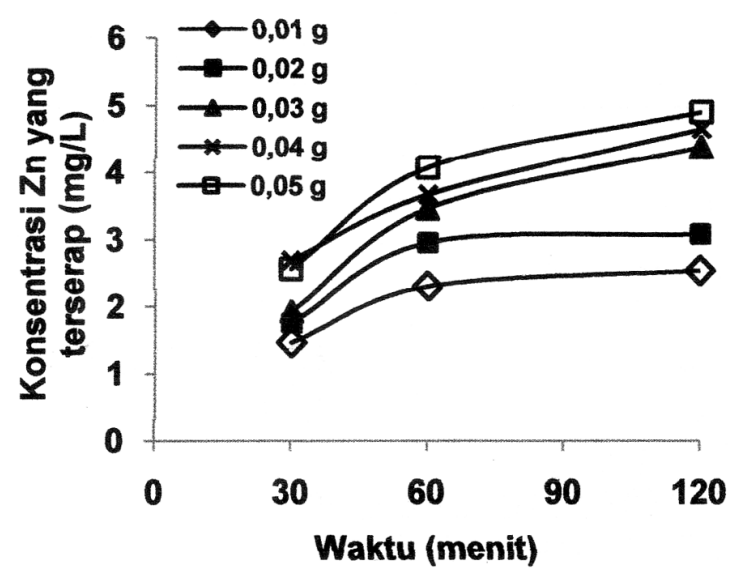

Gambar1. Hubungan antara waktu biosorpsi dengan konsentrasi Zn yang terserap pada berbagai jumlah biomassa

\section{Kapasitas Biosorpsi Logam Zn}

Kapasitas Biosorpsi logam Zn (Q) dihitung dengan menggunakan Persamaan (2) pada kondisi temperatur ruang, $\mathrm{pH} \mathrm{4,}$ pengadukan $800 \mathrm{rpm}$, volume larutan logam Zn (V) 0,1 L dan konsentrasi awal logam Zn $\left(C_{0}\right) \quad 7,6071 \mathrm{mg} / \mathrm{L}$. Hasil perhitungan kapasitas biosorpsi logam Zn dan efisiensinya dapat dilihat pada Tabel 3 .

Tabel 3. Biosorpsi logam Zn

Dada Tahol 2 danat dilihat hahusa kanacitac hinconrnci Inram 7n monindkat coirinn dannan

\begin{tabular}{|c|c|c|c|c|}
\hline $\begin{array}{c}\text { Jumlah } \\
\text { Biomassa (g) }\end{array}$ & $\begin{array}{l}\text { Waktu } \\
\text { (menit) }\end{array}$ & $\begin{array}{l}\text { Konsentrasi } \\
\text { akhir larutan } \mathrm{Zn} \text { (mgl) }\end{array}$ & $\begin{array}{c}\text { Efisiensi } \\
(\%)\end{array}$ & $\begin{array}{c}\text { Q } \\
\text { (mg logamig } \\
\text { biomassa) }\end{array}$ \\
\hline \multirow{3}{*}{0,01} & 30 & 6,1388 & 19,30 & 14,68 \\
\hline & 60 & 5,3038 & 30,28 & 23,03 \\
\hline & 120 & 5,0638 & 33,43 & 25,43 \\
\hline \multirow{3}{*}{0,02} & 30 & 5,8462 & 23,15 & 8,80 \\
\hline & 60 & 4,6538 & 38,82 & 14,77 \\
\hline & 120 & 4,5275 & 40,48 & 15,40 \\
\hline \multirow{3}{*}{0,03} & 30 & 5,6775 & 25,37 & 6,43 \\
\hline & 60 & 4,1488 & 45,46 & 11,53 \\
\hline & 120 & 3,2325 & 57,51 & 14,58 \\
\hline \multirow{3}{*}{0,04} & 30 & 4,9162 & 35,37 & 6,73 \\
\hline & 60 & 3,9450 & 48,14 & 9,16 \\
\hline & 120 & 2,9662 & 61,01 & 11,60 \\
\hline \multirow{3}{*}{0,05} & 30 & 5,0425 & 33,71 & 5,13 \\
\hline & 60 & 3,5450 & 53,40 & 8,12 \\
\hline & 120 & 2,7138 & 64,33 & 9,79 \\
\hline
\end{tabular}


bertambahnya waktu kontak. Nilai Kapasitas biosorpsi (Q) logam Zn tertinggi diperoleh pada waktu 120 menit dengan jumlah biomassa $0,01 \mathrm{~g}$ yaitu $25,43 \mathrm{mg} / \mathrm{g}$. Tabel 3 menunjukkan bahwa kapasitas biosorpsi logam Zn meningkat seiring dengan meningkatnya waktu tetapi penambahan jumlah biomassa tidak berpengaruh terhadap kapasitas biosorpsi logam Zn karena biomassa yang digunakan berupa mikroorganisme pasif/mati (non living cells). Penambahan biomassa berupa mikroorgnisme pasif menyebabkan kejenuhan pada proses penyerapan logam $\mathrm{Zn}$, hal ini sesuai dengan pernyataan Vijayaraghavanetal (2006) dalam Vijayaraghavan, K. dan Yeoung-Sang Yun (2008) yang menyatakan bahwa jumlah biosorben yang rendah menghasilkan uptake yang tinggi tetapi persentase efisiensi removal rendah.

Hubungan kapasitas biosorpsi logam Zn terhadap waktu dapat dilihat pada Gambar 2. Gambar 2 merupakan grafik regresi tipe logaritma yang menggambarkan korelasi antara data eksperimen dengan persamaan model matematika untuk kapasitas biosorpsi logam Zn. Nilai koefesien korelasi terbaik diperoleh pada kondisi jumlah biomassa $0,04 \mathrm{~g}$ dengan nilai koefisien korelasi $R^{2}=1$.

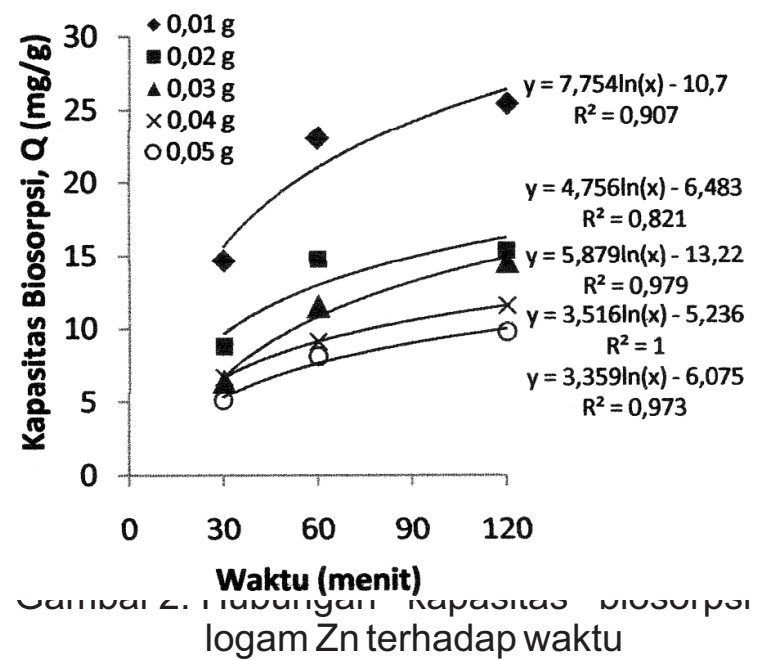

Efisiensi removal logam berbanding terbalik dengan serapan (uptake). Efisiensi tertinggi diperoleh pada waktu kontak 120 menit dengan jumlah biomassa $0,05 \mathrm{~g}$ yaitu
64,33\%. Efisiensi removal logam $\mathrm{Zn}$ dapat dilihat pada Gambar 3. Pada Gambar 3 menunjukkan adanya korelasi antara data eksperimen dengan model matematika. Nilai koefisien korelasi tertinggi dan mendekati 1 diperoleh pada kondisi jumlah biomassa $0,04 \mathrm{~g}$ yaitu $R^{2}=0965$.

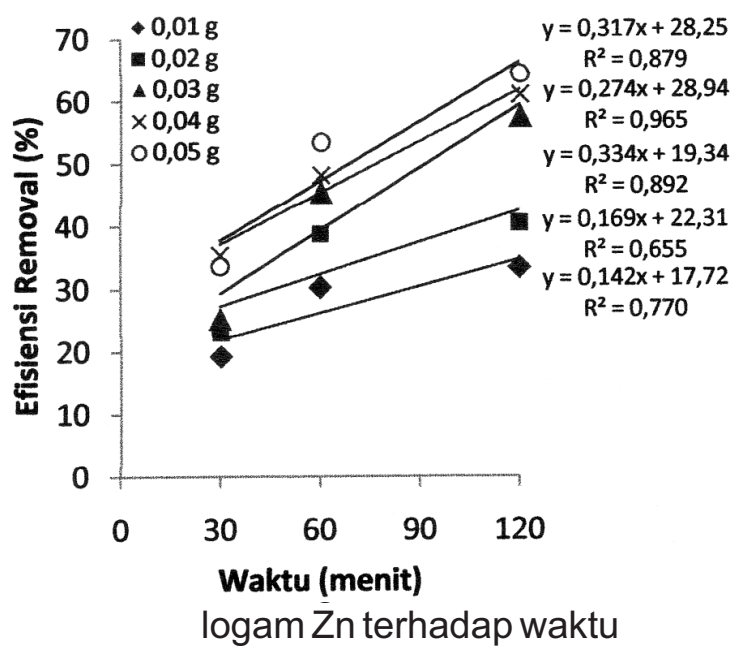

Jumlah biosorben sangat mempengaruhi keberhasilan biosorpsi. Dalam beberapa riset, jumlah biosorben yang rendah menghasilkan serapan (uptake) yang tinggi tetapi persentase efisiensi removal rendah (Aksu dan Cagatay, 2006; Vijayaraghavan et.al.,2006 dalam Vijayaraghavan et.al., 2008) seperti terlihat pada Gambar 2 dan 3. Jumlah biosorben sangat berpengaruh, semakin banyak jumlah biosorben yang terimobilasasi pada Ca-alginat akan meningkatkan jumlah logam Zn yang teradsorpsi (Gambar 1). Peningkatan jumlah logam $Z n$ yang teradsorpsi dapat disebabkan oleh bertambahnya gugus aktif yang mampu berikatan dengan logam (Esposito et.al., 2001 dalam Vijayaraghavan et.al., 2008).

\section{KESIMPULAN}

Biomassa campuran bakteri Pseudomonas aeruginosa dan Pseudomonas sp dapat digunakan sebagai biosorben yang diimobilisasi Ca-alginat dan mampu menurunkan limbah sintetik $\mathrm{Zn}$ pada kondisi operasi pH 4, temperatur ruang dan pengadukan 800 rpm. Kapasitas biosorpsi logam $\mathrm{Zn}$ tertinggi diperoleh sebesar 25,43 
$\mathrm{mg} / \mathrm{g}$ pada waktu 120 menit dan jumlah biomassa $0,01 \mathrm{~g}$. Kondisi optimum biosorpsi logam $\mathrm{Zn}$ berdasarkan korelasi antara data eksperimen dan model matematika diperoleh pada penambahan jumlah biomassa sebesar $0,04 \mathrm{~g}$ baik untuk kapasitas biosorpsi logam $\mathrm{Zn}$ maupun efisiensi removal logam $Z n$ dengan nilai $R^{2}$ masing-masing adalah 1 dan 0,965.

\section{DAFTAR PUSTAKA}

Ahalya, N., T.V. Ramachandra dan R.D. Kanamadi. 2004. Biosorption ofHeavy Metals. Bangalore. India. Centrefor Ecological Science. Indian Institute ofScience.

Alluri, H.K., S.R. Ronda, V.S. Settalluri, J. Singh. Bondili, Suryanarayana, V. dan Venkateshwar. 2007. Biosorption: An eco-friendly alternative for heavy metal removal. African Journal of Biotechnology. 6 (25): 2924-2931.

Chergui, A., M.Z. Bhakti, A. Chahboub, S. Haddoum, A. Selatnia dan G. A. Junter. 2007. Simultaneous biosorption of $\mathrm{Cu}^{2+}, \mathrm{Zn}^{2+}$ and $\mathrm{Cr}^{6+}$ from aqueous solution by Streptomyces rimosus. Desalination. 206:179-184.

Gazsó, L. G. 2001. The Key Microbial Processes in the Removal of Toxic Metals and Radionuclides from the Environment.Central European J. Occupational of Environ. Med., 7(3):178-185.

Gupta, R., P. Ahuja, S. Khan, R.K. Saxena, dan H. Mohapatra. 2000. Microbial Biosorbents: Meeting Challenges of Heavy Metal Pollution in Aqueous Solutions. Curr. Sci. 78(8):25.

Horsfall Jnr, M., F.E. Ogban dan E.E. Akporhonor. 2006. Recovery oflead and cadmium ions from metal-loaded biomass of wild cocoyam (Caladiumbicolor) using acidic, basic and neutraleluent solutions. Elec. J. Biotech. 9:152-156.

Hussein, H., S. F. Ibrahim, K. Kandeel, dan H. Moawad. 2004. Biosorption of Heavy Metals from Waste Water Using Pseudomonas sp. Electronic J. of Biotech.I. 7 (1).

Kresnawaty, I. dan T. Panji. 2007. Biosorpsi Logam Zn oleh Biomassa Saccharomyces cerevisiae. Menara Perkebunan. 75(2):80-92.

Vijayaraghavan, K. dan Yeoung-Sang Yun. 2008. Bacterial Biosorbents and Biosorption, Biotechnology Advances. 26: 266-291.

Wang, Jianlong dan Can, H. 2009. Biosorbent for Heavy Metals Removal and Their Future. Biotechnology Advances. 27:195-226.

Widjaja, T. 2008. Pengaruh Konsentrasi CaALGINAT pada Produksi Etanol dari Tetes Menggunakan Zymomonas mobilis dan Saccaromyces cerevieciea dengan Teknik Immobilisasi Sel. Dalam Prosiding Seminar Nasional Fundamental dan Aplikasi Teknik Kimia. Diselenggarakan oleh jurusan Teknik Kimia FTI-ITS. Surabaya. 